УДК 553.98

\title{
МОДЕЛИРОВАНИЕ ФАНЕРОЗОЙСКИХ ОЧАГОВ ГЕНЕРАЦИИ УГЛЕВОДОРОДОВ И ОЦЕНКА ИХ РОЛИ В ФОРМИРОВАНИИ ЗАЛЕЖЕЙ «ПАЛЕОЗОЙСКОЙ» НЕФТИ (ЮГО-ВОСТОК ЗАПАДНОЙ СИБИРИ)
}

\author{
Исаев Валерий Иванович 1 , \\ isaevvi@tpu.ru
}

\author{
Галиева Маргарита Фаритовна', \\ margaritagalieva@gmail.com
}

\author{
Лобова Галина Анатольевна 1 , \\ lobovaga@tpu.ru
}

\author{
Крутенко Даниил Сергеевич ${ }^{1}$, \\ dskrutenko@gmail.com
}

\author{
Осипова Елизавета Николаевна ${ }^{1}$, \\ osipovaen@tpu.ru \\ 1 Национальный исследовательский Томский политехнический университет, \\ Россия, 634050, г. Томск, пр. Ленина, 30.
}

\begin{abstract}
Актуальность. Промышленная нефтегазоносность отложений в палеозойском комплексе выявлена на всей площади Западной Сибири, значительные работы по оценке доюрских образований проводились на юго-востоке. Здесь открыто 13 залежей УВ в карбонатных, кремнисто-глинистых, песчаных и гравелитовых отложениях. Эти объекты отнесены к трудноизвлекаемой нефти, но являются инвестиционно привлекательными из-за приуроченности к территориям нефттепромыслов с уже развитой инфраструктурой. Исследованиями ставится и решается проблема моделирования мезозойских и палеозойских катагенетических очагов генерации углеводородов и оценки их роли в формировании залежей «палеозойской» нефтти.
\end{abstract} Цель: оценка роли фанерозойских очагов генерации углеводородов в формировании залежей «палеозойской» нефрти.

объект. Настоящая статья содержит постановку и решение задачи палеотектонических и палеотемпературных реконструкций палеозойско-мезозойских очагов генерации углеводородов в разрезе Герасимовского нефртегазоконденсатного месторождения, входящего в Останинскую группу месторождений Томской области. На месторождении коллекторы, обусловленные эпигенетическими процессами в древней коре выветривания в период 213-208 млн лет назад, формируют резервуары вскрытого бурением выветрелого и коренного палеозоя - кехорегской свиты нижнего карбона. На месторождении имеются измеренные пластовые температуры и определения отражательной способности витринита как в юрских интервалах разреза, так и в доюрских образованиях, а также документированные притоки фрлюида из доюрских горизонтов.

Методы. Палеореконструкции реализуются методом палеотемпературного моделирования. Используемая модель снимает необходимость завершающих калибровок по значениям отражающей способности витринита. Глубинный тепловой поток определяется решением обратных задач геотермии в оригинальной постановке, в два этапа. Первый этап заключается в определении плотности квазистационарного теплового потока, относимого к началу юрского времени. Второй этап состоит в определении значения теплового потока в силуре и его динамики до ранней юры. Решением прямых задач геотермии восстанавливается седиментационная и термическая история франерозойских материнских свит - палеозойских ларинской, мирной, чузикской, чагинской, кехорегской а также юрских тюменской и баженовской.

Результаты. В результате выполненного совместного палеотемпературного моделирования франерозойских очагов генерации углеводородов мезозойских и палеозойских осадочных бассейнов выявлены и изучены вероятные сингенетичные источники залежей углеводородов в выветрелом и коренном палеозое. Учет последовательности фаз генерации и эмиграции жидких и газообразных углеводородов, временного периода формирования коллекторов, данных генетических анализов нефоти позволяет идентифицировать нефти резервуаров палеозоя как «баженовские». A источником газа определяется «кехорегский» - породы доманикоидного типа кехорегской свиты.

Выводы. Палеотемпературные исследования разреза Герасимовского месторождения, раннее выполненное моделирование на Сельвейкинской площади глубокого бурения и на Останинском месторождении показывают, что альтернативные концепции «главного источника» палеозойских залежей углеводородов не являются взаимоисключающими. Представляется, что для палеозойских залежей источником жидких углеводородов (нефть), скорее всего, является верхнеюрская баженовская свита, а источником газообразных углеводородов (газа и газоконденсата) являются палеозойские породы доманикоидного типа.

\section{Ключевые слова:}

Палеозойский нефтегазоносный комплекс, фанерозойские источники углеводородов,

палеотемпературное моделирование очагов генерации, сингенетичные источники «палеозойской» нефтти, Останинская группа месторождений Томской области.

\section{Введение}

В Западной Сибири месторождения углеводородов (УВ) находятся на поздней стадии разработки: ресурсная база, прежде всего, промышленно значимого юрского горизонта в значительной степени исчерпана. Необходимо повышать коэффициент извлечения нефти на действующих месторождениях, выполнять поиски и осваивать зоны нефтегазонакопления в но- 
вых стратиграфических горизонтах, включая сланцевую формацию баженовской свиты, а также доюрский нефтегазоносный комплекс (НГК). Все перечисленные объекты отнесены к трудноизвлекаемой нефти, но являются инвестиционно привлекательными в контексте приуроченности к территориям нефтепромыслов с уже развитой инфраструктурой.

Промышленная нефтегазоносность отложений в доюрском (палеозойском) НГК выявлена на всей площади Западной Сибири (рис. 1). Значительные работы по оценке нефтегазоносности доюрских отложений проводились на юго-востоке, на территории
Томской области (Нюрольская мегавпадина), в пределах которой открыто 13 залежей УВ в карбонатных, кремнисто-глинистых, песчаных и гравелитовых отложениях.

Разнообразие подходов к проблеме формирования месторождений УВ в палеозойском НГК Западной Сибири, вариантный выбор фактических материалов и различные методы их интерпретации привели к многообразию концепций о нефтегазоносности палеозойских отложений и, как следствие, к существенной неоднозначности стратегии поисков залежей в палеозойском комплексе.

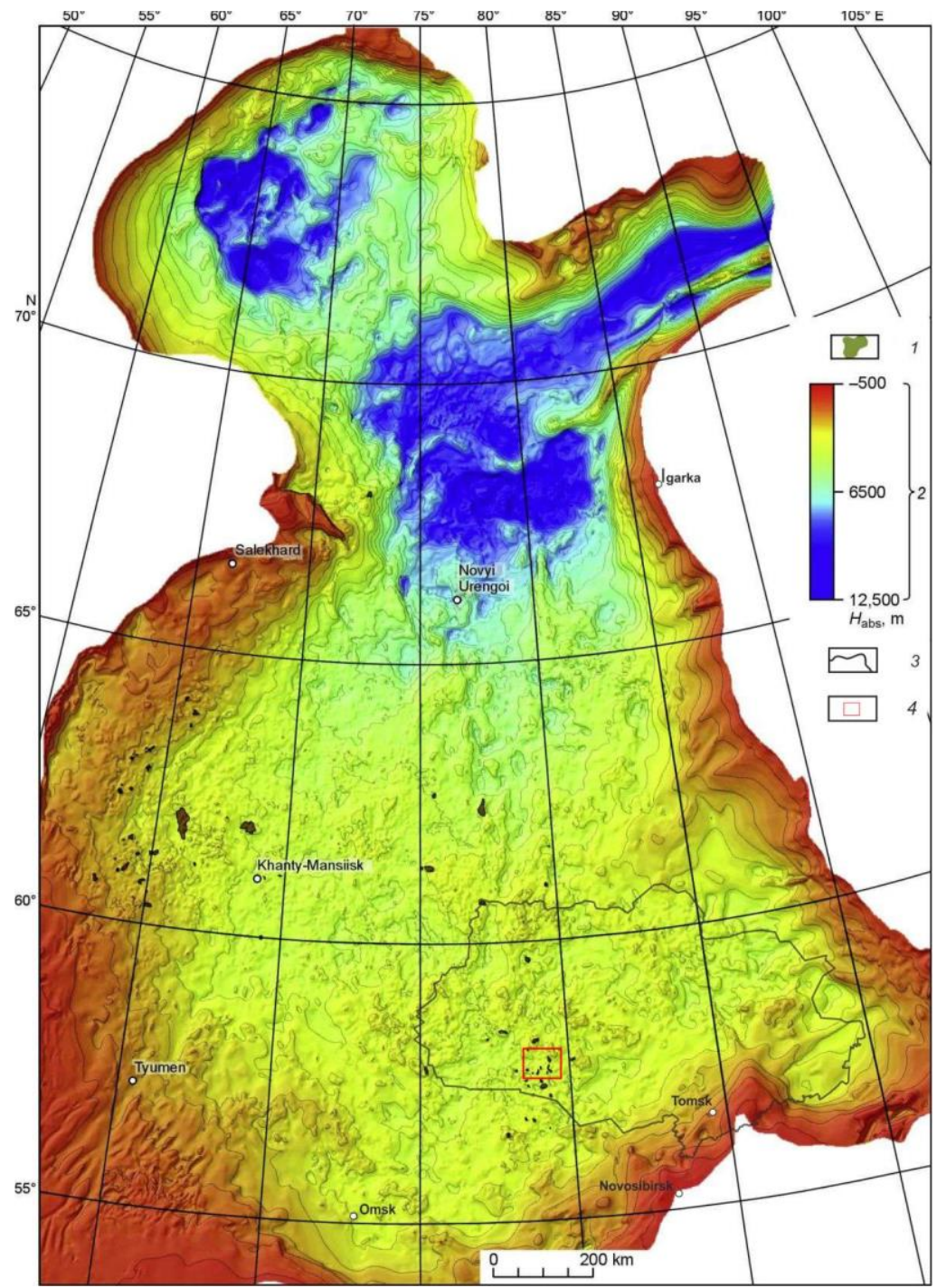

Pис. 1. Положение месторождений УВ доюрского НГК Западно-Сибирской плиты на структурной карте по реперному сейсмическому горизонту, приуроченному к подошве юрских отложений (по [4]): 1 - месторождение; 2 - шкала глубин кровли доюрских образований; 3 - административная граница Томской области; 4 - район Останинской группы месторождений

Fig. 1. Location of fields (producing hydrocarbons from the pre-Jurassic oil and gas play (OGP) of Western Siberian Plate) on structure map of the reference seismic horizon associated with bottom of the Jurassic clastic rocks (by [4]): 1 hydrocarbon field; 2 - depth scale of top of the pre-Jurassic clastic rocks; 3 - Tomsk Region boundary; 4 - the Ostanino group of fields territory

О концепции «главного источника» палеозойской нефти высказываются и обосновываются два варианта. По первой концепции, на основе биомаркерного анализа нефтей, палеозойские отложения рассматриваются как нефтеаккумулирующий комплекс с собственныли материнскими толщами, обуславливающими восходящую миграцию углеводородных флюидов [1]. По второй концепции, основанной на коррелящии нефтей па- 
леозойских залежей и битумоидов юрских материнских пород, осуществляется нисходящая межпластовая миграция УВ из юрских толщ в доюрские образования [2].

Настоящими исследованиями ставится и решается проблема моделирования палеотемпературнылм методом мезозойских и палеозойских очагов генерации УВ и оценки их роли в формировании залежей «палеозойской» нефти.

Первый опыт и результаты совместного палеотемпературного моделирования мезозойских и палеозой- ских очагов генерации УВ фанерозойских осадочных бассейнов получены для палеозойско-мезозойскокайнозойского разреза Сельвейкинской площади глубокого бурения [3].

Установлено, что в разрезе Сельвейкинской площади (рис. 2, а, скважина 2), на которой вскрытая кровля палеозоя представлена верхнедевонскими отложениями, источником газопроявлений коры выветривания (пласт $\mathrm{M}_{1}$ ) и кровли палеозоя (пласт М) являются породы доманикоидного типа девонской чагинской свиты.

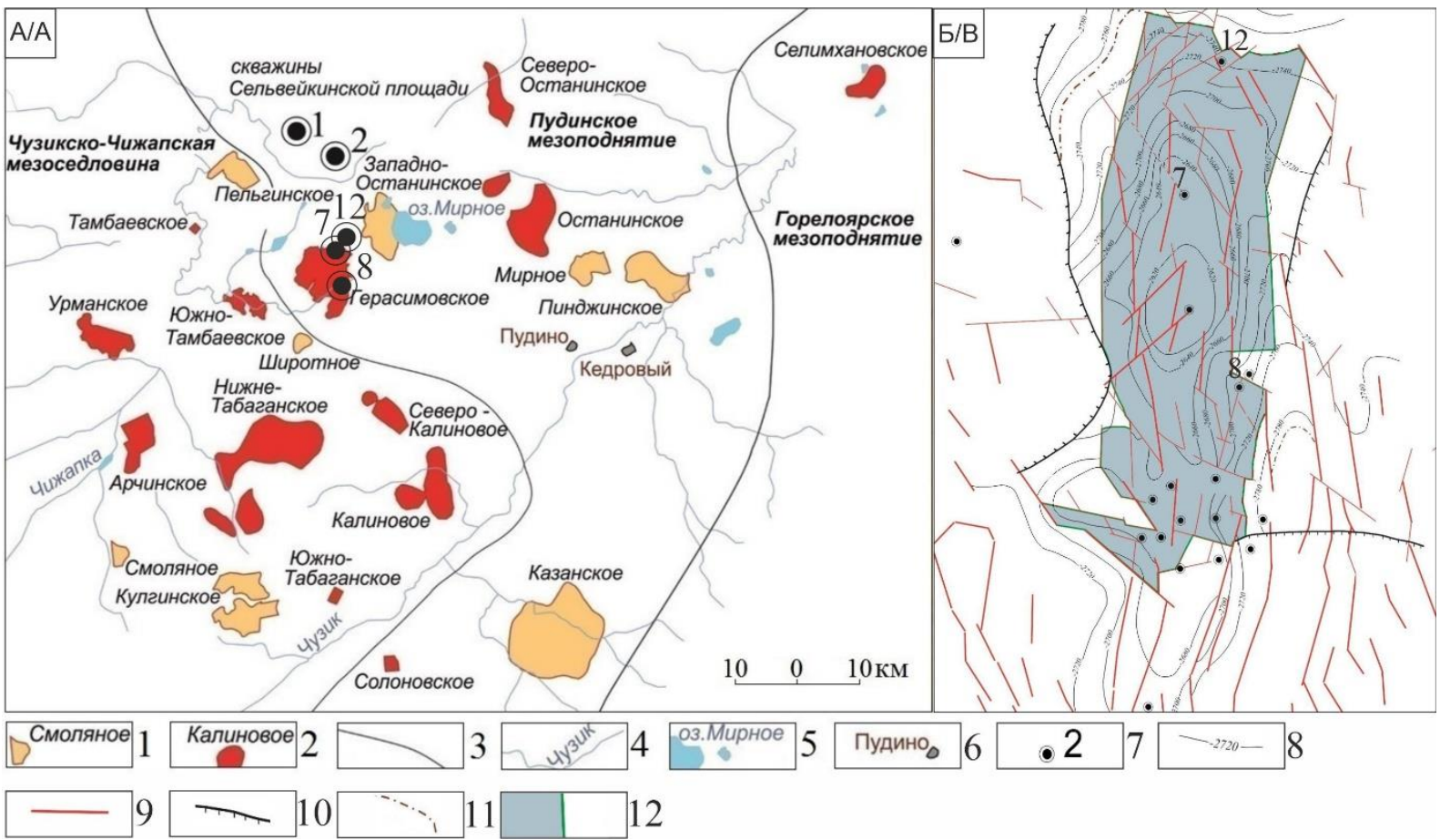

Pис. 2. Останинская группа месторождений (А) и Герасимовское нефтегазоконденсатное месторождение (Б). 1, 2 - месторождение УВ с залежами в нефтегазоносных комплексах: 1 - юрских, 2 - юрских и доюрском; 3 - граница тектонического элемента [5]; 4 - речная сеть; 5 - озеро; 6 - поселение; 7 - исследуемая скважина глубокого бурения; 8 - сейсмоизогипса по подошве осадочного чехла; 9 - тектоническое нарушение; 10 - граница коллектора коренного палеозоя (пласт М); 11 - контур ВНК пласта М; 12 - контур запасов категории C1

Fig. 2. The Ostanino group of hydrocarbon fields (A) and the Gerasimov oil-gas condensate field (B). 1, 2 - a field with deposits in: 1 - the Jurassic OGP, 2 - the Jurassic and pre-Jurassic OGP; 3 -tectonic structure boundary [5]; 4 - river system; 5 -lake; 6-inhabited area; 7 - deep well of study and its number; 8 - seismic isohypse along the bottom of sediment cover; 9 - disjunctive fault; 10 - the border of the inner Paleozoic reservoir $\left(M_{1}\right.$ formation); 11 - oilwater contact in $M_{1}$ formation ; 12 - outlined reserves of C1 category

В работе [6] ставилась и решалась задача моделирования палеозойско-мезозойских очагов генерации УВ в разрезе Останинского нефтегазоконденсатного месторождения (рис. 2, a). Останинское месторождение, в отличие от Сельвейкинской площади, имеет промышленные притоки УВ в доюрских пластах М и $\mathrm{M}_{1}$.

Установлено, что в разрезе Останинского месторождения, на котором вскрытая кровля палеозоя также представлена верхнедевонскими отложениями, основным («главным») источником УВ доюрских залежей является юрская «баженовская нефть». А роль девонского чагинского источника газа для пластов М и $\mathrm{M}_{1}$ незначительна.
Таким образом, результаты палеотемпературных исследований разрезов Сельвейкинской площади и Останинского месторождения показывают, что альтернативные концепции «главного источника» палеозойских залежей УВ не являются взаимоисключающими. Представляется, что источником жидких УВ (нефть), скорее всего, является верхнеюрская баженовская свита, а источником газообразных УВ (газа и газоконденсата) - палеозойские породы доманикоидного типа.

Настоящая статья содержит постановку и решение задачи палеотектонических и палеотемпературных реконструкций палеозойско-мезозойских очагов генерации УВ в разрезе Герасимовского нефтегазоконденсатного месторождения (рис. 2). 
На Герасимовском месторождении для вскрытых палеозойских образований по отражательной способности витринита (ОСВ) установлена степень катагенеза $\mathrm{R}_{\mathrm{vt}}^{0}=1,17$. Особый интерес к Герасимовскому месторождению обусловлен следующим. В отличие от Сельвейкинской площади и Останинского месторождения, на которых вскрытая кровля палеозоя представлена девонскими отложениями $\left(\mathrm{D}_{3}\right)$, на Герасимовском месторождении кровля палеозоя сложена образованиями карбона $\left(\mathrm{C}_{1}\right)$.

Важно обратить внимание на еще один аспект актуальности настоящих исследований. Стало достаточно привычным и уверенно выполняемым моделирование «современных» (мезозойско-кайнозойских) осадочных бассейнов.

И в работах российских исследовательских школ, и в публикациях зарубежных исследователей моделирование катагенетических очагов генерации нефти и газа обычно делается, начиная с 210 млн лет назад, т. е. для мезозойско-кайнозойского осадочного бассейна $[7,8]$.

В российской практике бассейнового моделирования известное исключение составляет геологогеотермическая модель палеозойско-мезозойского осадочного чехла северо-восточной части Баренцевоморского шельфа, представленная лабораторией тепломассопереноса ГИН РАН [9], и геотермическая модель верхнепротерозойско-палеозойских комплексов Предъенисейского осадочного бассейна, аффилированная лабораторией теоретических основ прогноза нефтегазоносности ИНГГ СО РАН [10].

И в работах зарубежных исследований есть примеры применения метода геотемпературного моделирования палеобассейнов $[11,12]$. В работе [13] авторы восстанавливают термическую историю палеозойских (нижнедевонских) пород на территории Германии. Моделирование выполнялось для периода, начиная с 400 млн лет назад. В работе [14] проиллюстрирован пример сопряженного со структурными реконструкциями моделирования изменения тепловых потоков, начиная с ордовика. В публикации [15] применяются данные о поверхностных тепловых потоках для вычисления температур в нефтегазоперспективных объектах раннепалеозойского возраста, характеризующихся глубиной залегания 6-8 км.

Но в работах зарубежных и российских исследователей, как правило, за рамками опубликованных материалов остаются конкретные схемы и параметры методик и технологий моделирования. Вместе с тем при включении в историко-геологический анализ отложений «палеобассейнов» [16] восстановление истории генерационных и аккумуляционных процессов существенно осложняется. Поэтому настоящая статья представляется интересной и полезной, так как не только конкретизирует круг проблемных вопросов методологии и методики моделирования «палеобассейнов», но и дает пример технологии их возможного решения.

\section{Характеристика Герасимовского месторождения}

Согласно [17], площадь Герасимовского месторождения расположена на границе внутригеосинклинального Межовского срединного массива и ВасюганПудинского антиклинория и приурочена к восточной части наложенной Нюрольской впадины, сложенной карбонатными, терригенно-карбонатными и терригенными толщами. По [5], Герасимовская структура находится в зоне сочленения Чузикско-Чижапской мезоседловины и Пудинского мезоподнятия, осложняя его юго-западный склон (рис. 2, a). Герасимовское нефтегазоконденсатное месторождение относится к многопластовым, со сложным геологическим строением.

Промышленная нефтегазоносность месторождения связана с резервуарами доюрского (пласты М, $\mathrm{M}_{1}$ ), нижнеюрского (пласт $Ю_{15}$ ), среднеюрского (пласты $Ю_{14}, Ю_{12}, Ю_{11}, Ю_{10}, Ю_{2}$ ) и верхнеюрского (пласты $\left.Ю_{1}^{1-2}, Ю_{1}^{3}, Ю_{1}^{4}\right)$ НГК. Фазовое состояние залежей следующее: пласты $\mathrm{M}_{1}, Ю_{15}, Ю_{14}, Ю_{12}, Ю_{11}$ нефтегазовые, М и $Ю_{10}$ - нефтегазоконденсатные, $\mathrm{Ю}_{2}, Ю_{1}^{1-2}, Ю_{1}^{3}, Ю_{1}^{4}$ - газоконденсатные.

Пласты группы Ю (наунакская, тюменская свиты) - средне-, мелкозернистые песчаники, реже - крупнозернистые алевролиты.

Резервуар выветрелого палеозоя - пласт $M$ представлен кавернозно-трещиноватыми кремнистыми, реже глинисто-кремнистыми породами с органогенным детритом. Отмечается значительное изменение качества коллекторов в резервуаре по латерали, вплоть до полного их уплотнения.

Резервуар коренного палеозоя - пласт $M_{l}$, выполнен в основном известняками органогенными кремнистыми с прослоями мергелей и аргиллитов. В скважине Герасимовская 12 вскрыты нижнекарбоновые черные известковистые силициты.

Глубокое поисковое бурение на 17 скважинах Герасимовского месторождения вскрыло образования доюрского фундамента (рис. 2, б). Пласт М является основным промышленным нефтяным объектом (табл. 1). В скважине Герасимовская 8 из доюрского горизонта М (интервал 2854-2861 м) зафиксирован приток безводной нефти, дебит $127 \mathrm{~m}^{3} /$ сут. Приток нефти дебитом $8 \mathrm{~m}^{3} /$ сут получен из пласта $\mathrm{M}_{1}$ (интервал 2867-2879 м) в скважине Герасимовская 12. Приток газа дебитом 5,5 тыс. м³ сут получен из интервала 2746-2758 м $\left(\mathrm{M}_{1}+\mathrm{M}\right)$ в скважине Герасимовская 7. Непромышленные притоки нефти получены из пласта $Ю_{7}$ в скважине Герасимовская 12 и газоконденсатной смеси в скважине Герасимовская 7.

Bblбор скважины Герасимовская 12 для выполнения палеотектонических и палеотемпературных реконструкций предопределен обеспеченностью измеренными геотемпературами как в юрских интервалах разреза, так и в доюрских образованиях, а также наличием притоков из доюрских пластов. Скважина вскрыла выветрелую часть фундамента мощностью 57 м на глубине 2842 м, образования коренного палеозоя - с проходкой 111 м. 
Таблица 1. Герасимовское нефтегазоконденсатное месторождение. Опробование глубоких скважин, пройденных в образованиях коренного палеозоя (по материалам «дел скважин»)

Table 1. The Gerasimov oil-gas condensate field. Results of testing wells, exposed the inner Paleozoic rocks (applying well history data)

\begin{tabular}{|c|c|c|c|}
\hline $\begin{array}{l}\text { Свита (горизонт, пласт) } \\
\text { Suite (horizon, formation) }\end{array}$ & $\begin{array}{l}\text { Интервал, м } \\
\text { Interval, m }\end{array}$ & $\begin{array}{c}\text { Тип флюида } \\
\text { Fluid type } \\
\end{array}$ & $\begin{array}{l}\text { Дебит, } \mathrm{m}^{3} / \text { сут } \\
\text { Rate, } \mathrm{m}^{3} / \text { day }\end{array}$ \\
\hline \multicolumn{4}{|c|}{ Скважина Герасимовская 7/The well Gerasimov no. 7} \\
\hline $\begin{array}{l}\text { Выветрелый палеозой (пласт } \mathrm{M})+ \\
\text { Кехорегская свита }\left(\mathrm{C}_{1} \mathrm{kh}\left(\text { (пласт } \mathrm{M}_{1}\right)\right) \\
\text { Weathered Paleozoic rocks }(\mathrm{M} \text { formation })+ \\
\text { Kehoreg suite }\left(\mathrm{C}_{1} \mathrm{kh}\left(\mathrm{M}_{1} \text { formation }\right)\right)\end{array}$ & $2746-2758$ & $\begin{array}{l}\text { нефть, газ } \\
\text { oil, gas }\end{array}$ & $\begin{array}{l}\text { 20; } 5,5 \text { тыс. } \mathrm{m}^{3} / \text { сут } \\
20 ; 5,5 \text { thous. } \mathrm{m}^{3} / \text { day }\end{array}$ \\
\hline $\begin{array}{l}\text { Выветрелый палеозой (пласт M) } \\
\text { Weathered Paleozoic rocks (M formation) }\end{array}$ & $2746-2754$ & $\begin{array}{c}\text { нефть, газ } \\
\text { oil, gas }\end{array}$ & $\begin{array}{c}8,2 ; 2,1 \text { тыс. } \mathrm{m}^{3} / \text { сут } \\
8,2 ; 2,1 \text { thous. } \mathrm{m}^{3} / \text { day }\end{array}$ \\
\hline $\begin{array}{l}\text { Тюменская свита }\left(\mathrm{J}_{1-2} \mathrm{tm}\left(\text { пласт } \mathrm{Ю}_{7}\right)\right) \\
\text { Tyumen suite }\left(\mathrm{J}_{1-2} \mathrm{tm}\left(\mathrm{Yu}_{7} \text { formation }\right)\right)\end{array}$ & 2704-2712 & $\begin{array}{c}\text { газоконденсатная смесь } \\
\text { (конденсат+газ) } \\
\text { gas condensate mixture } \\
\text { (condensate+gas) }\end{array}$ & $\begin{array}{l}16 \text { тыс. } \mathrm{m}^{3} / \text { сут } \\
16 \text { thous. } \mathrm{m}^{3} / \text { day }\end{array}$ \\
\hline $\begin{array}{l}\left.\text { Тюменская свита }\left(\mathrm{J}_{1-2} \mathrm{tm} \text { (пласт } \mathrm{Ю}_{2}\right)\right) \\
\text { Tyumen suite }\left(\mathrm{J}_{1-2} \mathrm{tm}\left(\mathrm{Yu}_{2} \text { formation }\right)\right)\end{array}$ & $2562-2568$ & $\begin{array}{l}\text { конденсат, газ } \\
\text { condensate, gas }\end{array}$ & $\begin{array}{l}1,2 ; 10,8 \text { тыс. } \mathrm{m}^{3} / \text { сут } \\
1,2 ; 10,8 \text { thous. } \mathrm{m}^{3} / \text { day }\end{array}$ \\
\hline \multicolumn{4}{|c|}{$\begin{array}{l}\text { Скважина Герасимовская } 12 \\
\text { The well Gerasimov no. } 12\end{array}$} \\
\hline $\begin{array}{l}\left.\text { Кехорегская свита }\left(\mathrm{C}_{1} \mathrm{kh} \text { (пласт } \mathrm{M}_{1}\right)\right) \\
\text { Kehoreg suite }\left(\mathrm{C}_{1} \mathrm{kh}\left(\mathrm{M}_{1} \text { formation }\right)\right)\end{array}$ & $2902-2917$ & $\begin{array}{c}\text { пластовая вода с малым количе- } \\
\text { ством растворенного газа } \\
\text { reservoir water with little amount } \\
\text { of dissolved gas }\end{array}$ & 1,1 \\
\hline $\begin{array}{l}\text { Кехорегская свита }\left(\mathrm{C}_{1} \mathrm{kh}\left(\text { пласт } \mathrm{M}_{1}\right)\right) \\
\text { Kehoreg suite }\left(\mathrm{C}_{1} \mathrm{kh}\left(\mathrm{M}_{1} \text { formation }\right)\right)\end{array}$ & $2867-2879$ & $\begin{array}{c}\text { нефть, вода, газ } \\
\text { oil, water, gas }\end{array}$ & $\begin{array}{c}8 ; 3,5 ; 0,5 \text { тыс. } \mathrm{m}^{3} / \text { сут } \\
8 ; 3,5 ; 0,5 \text { thous. } \mathrm{m}^{3} / \text { day }\end{array}$ \\
\hline $\begin{array}{l}\text { Выветрелый палеозой (пласт M) } \\
\text { Weathered Paleozoic rocks (M formation) }\end{array}$ & $2847-2860$ & $\begin{array}{c}\text { нефть } \\
\text { oil } \\
\end{array}$ & 3,5 \\
\hline $\begin{array}{l}\text { Тюменская свита }\left(\mathrm{J}_{1-2} \mathrm{tm}\right)+ \\
\text { Выветрелый палеозой (пласт } \mathrm{M}) \\
\text { Tyumen suite }\left(\mathrm{J}_{1-2} \mathrm{tm}\right)+ \\
\text { the weathered Paleozoic rocks (M formation) }\end{array}$ & $2838-2859$ & $\begin{array}{c}\text { нефть } 90 \% \text {, вода } 10 \% \\
\text { oil } 90 \% \text {, water } 10 \%\end{array}$ & 13 \\
\hline $\begin{array}{l}\text { Тюменская свита }\left(\mathrm{J}_{1-2} \mathrm{tm}\left(\text { пласт } Ю_{7}\right)\right) \\
\text { Tyumen suite }\left(\mathrm{J}_{1-2} \mathrm{tm}\left(\mathrm{Yu}_{7} \text { formation }\right)\right)\end{array}$ & $2770-2780$ & $\begin{array}{c}\text { нефть } \\
\text { oil }\end{array}$ & 0,4 \\
\hline $\begin{array}{l}\text { Наунакская свита }\left(\mathrm{J}_{3} \mathrm{nn}\right) \\
\text { Naunak suite }\left(\mathrm{J}_{3} \mathrm{nn}\right)\end{array}$ & $2565-2570$ & $\begin{array}{c}\text { практически «сухой» } \\
\text { almost barren }\end{array}$ & - \\
\hline \multicolumn{4}{|c|}{ Скважина Герасимовская 8/The well Gerasimov no. 8} \\
\hline $\begin{array}{l}\text { Выветрелый палеозой (пласт M) } \\
\text { Weathered Paleozoic rocks (M formation) }\end{array}$ & $2854-2861$ & $\begin{array}{c}\text { нефть } \\
\text { oil }\end{array}$ & 127 \\
\hline $\begin{array}{l}\text { Выветрелый палеозой (пласт M) } \\
\text { Weathered Paleozoic rocks (M formation) }\end{array}$ & $\begin{array}{l}2865-2870 \\
2854-2861\end{array}$ & $\begin{array}{c}\text { нефть } \\
\text { oil }\end{array}$ & 80 \\
\hline $\begin{array}{l}\text { Тюменская свита }\left(\mathrm{J}_{1-2} \mathrm{tm}\right)+ \\
\text { Выветрелый палеозой (пласт } \mathrm{M}) \\
\text { Tyumen suite }\left(\mathrm{J}_{1-2} \mathrm{tm}\right)+ \\
\text { weathered Paleozoic rocks (M formation) }\end{array}$ & $2828-2847$ & $\begin{array}{c}\text { нефть } \\
\text { oil }\end{array}$ & 47 \\
\hline
\end{tabular}

\section{О параметризации модели}

\section{Герасимовского месторождения}

Литолого-стратиграфическая разбивка («дело скважины») послужила основой параметризации вскрытого мезозойско-кайнозойского разреза скважины 12 . Реконструкция мощностей не вскрытого силурийскокаменноугольного стратиграфического разреза выполнена с учетом [18].

В палеозойском разрезе учтены перерывы в осадконакоплении [19]. Первый (первая половина эйфельского века) - непродолжительный, порядка 3 млн лет. Второй (с началом в среднекаменноугольную эпоху) - более продолжительный, порядка 105 млн лет. Во второй перерыв размывались каменноугольные отложения - елизаровская $\mathrm{C}_{2} \mathrm{elz}$, средневасюганская $\mathrm{C}_{1-2} \mathrm{SV}$ и частично кехорегская $\mathrm{C}_{1} \mathrm{kh}$ свиты. O перерыве в осадконакоплении и размыве отложений свидетельствуют вскрытые на забое скважины 12 визейские отложения раннего карбона, возраст которых подтверждается по комплексу фораминифер. Таким образом, толщина размытых палеозойских отложений составляет не менее 1000 м.
Как источники УВ для горизонтов выветрелого и коренного палеозоя предполагаются потенциально нефтематеринские свиты [20, 21]: палеозойские породы доманикоидного типа - ларинской $\left(\mathrm{S}_{1} \mathrm{lr}\right)$, мирной $\left(\mathrm{D}_{1} \mathrm{mr}\right)$, чузикской $\left(\mathrm{D}_{2} \mathrm{cz}\right)$, чагинской $\left(\mathrm{D}_{3} \mathrm{cg}\right)$, кехорегской $\left(\mathrm{C}_{1} \mathrm{kh}\right)$ свит, а также юрские битуминозные породы тюменской $\left(\mathrm{J}_{1-2} \mathrm{tm}\right)$ и баженовской $\left(\mathrm{J}_{3} \mathrm{bg}\right)$ свит.

\section{О методике и технологии моделирования}

Величина и динамика теплового потока из основания осадочного чехла является одним из основных параметров бассейнового моделирования [22, 23]. Его количественная оценка сложна из-за связей с тектоникой, поверхностными процессами и климатом, и поэтому его моделирование требует комплексного подхода [24]. Именно такой подход к расчету теплового потока обеспечивает применяемая нами методика, которая предполагает выполнение структурно-тектонических реконструкций, учет климатических изменений, а также использование данных о распределении геотемператур как совре- 
менных (данные испытаний скважин), так и древних (замеры ОСВ).

Палеоструктурные и палеотемпературные реконструкции реализуются посредством компьютерного комплекса 1D моделирования TeploDialog [7]. В отличие от известных систем бассейнового моделирования (например, ГАЛА, Temis, PetroMod [25]), используемая нами модель снимает необходимость выполнения на завершающем этапе калибровок по ОСВ [26].

В качестве верхнего граничного условия модели принимается климатический «местный» (для юговостока Западной Сибири) вековой ход температур, с раннемелового - 120 млн лет назад [27]. «Местный» вековой ход был дополнен палеоклиматическими реконструкциями, начиная с 450 млн лет назад [28], в основе которых лежит совместный анализ литологических и палеонтологических индикаторов климата, а также изотопного состава кислорода.

Глубинный тепловой поток - нижнее граничное условие - это решение обратных задач геотермии в оригинальной постановке [29], в два этапа.

Первый этап заключался в решении обратной задачи - определении значения плотности квазистационарного теплового потока $54 \mathrm{mBT} / \mathrm{m}^{2}$, относимого к началу юрского времени. Здесь в качестве входных параметров использованы измерения пластовых температур и замеры ОСВ в интервалах юрских отложений.

Bторой этап состоял в решении последующей обратной задачи - определении значения плотности теплового потока в силуре $224 \mathrm{MB} / \mathrm{M}^{2}$ и его динамики до ранней юры, с использованием в качестве «наблюденных» геотемператур измерения ОСВ палеозойских образований. Окончание герцинского времени определило резкий спад плотности теплового потока в триасе.

Критерием корректности результатов моделирования плотности теплового потока служит оптимальная согласованность («невязка») расчетных современных и палеотемператур с измеренными («наблюденными») - пластовыми и геотемпературами, пересчитанными из ОСВ. В нашем случае эта «невязка» оптимальная не превышает $\pm 2{ }^{\circ} \mathrm{C}$ (табл. 2, рис. 3), т. е. соответствует погрешности наблюденных значений [30, 31].

Решением прямых задач геотермии с использованием расчетных значений и динамики глубинного теплового потока выполнено восстановление седиментационной и термической истории для фанерозойских потенциально материнских свит - ларинской, мирной, чузикской, чагинской, кехорегской а также тюменской и баженовской (рис. 4).

\section{Анализ и оценка результатов}

Геотемпературы и их динамика главной зоны нефтеобразования (ГЗН), или главной фазы нефтеобразования (ГФН), так называемое «oil window» $\left(90-130^{\circ} \mathrm{C}\right)$, определяют реализацию нефтематеринской формации [32]. Другие факторы, такие как химическая среда и давление, обычно рассматриваются как менее значимые [33]. Собственную роль в формировании залежей
УВ играет главная зона газообразования (ГЗГ), или главная фаза газообразования (ГФГ) $130-190{ }^{\circ} \mathrm{C}$, характеризующаяся интенсивным образованием углеводородных газов, главным образом метана и газоконденсата [34]. Геотемпературы более $190^{\circ} \mathrm{C}$ разрушительные для углеводородов. По некоторым оценкам [35] углеводородные газы могут образовываться и при более высокотемпературном режиме - в окне $160-220^{\circ} \mathrm{C}$.

Доюрский НГК представлен двумя резервуарами: выветрелого (горизонт М) и коренного $\left(\mathrm{M}_{1}\right)$ палеозоя. Триасовая кора выветривания, вероятно, играющая ключевую роль в генезисе резервуаров, формировалась в период 213-208 млн лет назад, однако была подвергнута денудационным процессам и не сохранилась. То есть принимаем концепцию, согласно которой резервуары палеозоя генетически обусловлены преимущественно эпигенетическими метеорными и гидротермальными процессами в коре выветривания [36]. Эти резервуары, представленные вторичными коллекторами, сформировались не ранее 213-208 млн лет назад, их геотемпературы не превышали $130{ }^{\circ} \mathrm{C}$. В то же время принимаем концепцию вертикальной межпластовой миграции углеводородов $[1,2]$, включая миграцию как вверх, так и вниз по разрезу.

Последовательно анализируя периоды «работы» катагенетических очагов генерации нефти (ГФН), газа и газоконденсата (ГФГ) в каждой из семи фанерозойских потенциально материнских свит (рис. 4) и сопоставляя эти периоды со временем формирования палеозойских резервуаров, сделаем оценку возможности аккумуляции и сохранности углеводородов в виде залежей палеозойских пластов.

Нужно отметить (рис. 4), что максимальный прогрев палеозойского разреза наблюдается к началу размыва каменноугольных отложений, 313 млн лет назад. В это время разрез характеризуется максимальной мощностью в доюрское время. Геотемпературы в наиболее погруженной ларинской свите достигают $540{ }^{\circ} \mathrm{C}$, а, соответственно, выше по разрезу: в мирной - 360, в чузикской - 300, в чагинской -240 , в кехорегской $-180^{\circ} \mathrm{C}$.

Катагенетическая история ларинской свиты $\left(S_{l} l r\right)$. Ларинская свита вошла в ГЗН 422 млн лет назад, но ненадолго - на 3 млн лет, в ГЗГ - 419 млн лет назад на 12 млн лет. Таким образом, нефтяной потенциал ларинского источника реализован 419 млн лет назад, газовый потенциал реализован 407 млн лет назад. С этого времени свита вошла в зону геотемператур, превышающих $190^{\circ} \mathrm{C}$, т. е. деструктивных для углеводородов. В зону деструктивных геотемператур ларинская свита погружалась дважды: (407-163) млн лет назад и $(95,0-0)$ млн лет назад. Таким образом, УВ ларинской свиты подвергались действию разрушительных геотемператур в общей сложности 339 млн лет, в том числе 244 млн лет до формирования коллекторов палеозойских резервуаров. Вполне ясно, что УВ ларинского источника не могли аккумулироваться в этих резервуарах.

Катагенетическая история мирной свиты $\left(D_{l} m r\right)$. Свита вошла в ГЗН 386 млн лет назад на 8 млн лет, в ГЗГ - 378 млн лет назад на весьма про- 
должительное время - 31 млн лет. Нефтяной потенциал мирного источника реализован 378 млн лет назад, газовый потенциал реализован 347 млн лет назад. На этом временном этапе свита вошла в зону геотемператур, деструктивных для углеводородов. В зоне деструктивных геотемператур мирная свита находилась 134 млн лет (347-213), то есть еще до формирования коллекторов палеозойских резервуаров. Ясно, что УВ мирного источника не могли аккумулироваться в резервуарах палеозоя.

Таблица 2. Скважина Герасимовская 12. Измеренные и расчетные температуры, рассчитанный тепловой поток

Table 2. Well Gerasimov no. 12. Experimental and calculated temperatures, estimated heat flow

\begin{tabular}{|c|c|c|c|c|c|}
\hline \multirow[b]{2}{*}{$\begin{array}{l}\text { Приуроченность/ } \\
\text { глубина, м } \\
\text { Confinedness/ } \\
\text { depth, m }\end{array}$} & \multicolumn{4}{|c|}{ Температура/Temperature, ${ }^{\circ} \mathrm{C}$} & \multirow[b]{2}{*}{$\begin{array}{c}\text { Тепловой поток, мВт/м²/ } \\
\text { динамическая характеристика } \\
\text { Deep heat flow, } \mathrm{mW} / \mathrm{m}^{2} / \\
\text { dynamic characteristic }\end{array}$} \\
\hline & $\begin{array}{c}\text { Пластовая } \\
\text { измеренная } \\
\text { Well test } \\
\text { temperature }\end{array}$ & \begin{tabular}{|c|} 
По $\mathrm{OCB}^{*}$ \\
$\left(R_{\mathrm{vt}}^{0}\right)$ \\
By VR* \\
$\left(R_{\mathrm{vt}}^{0}\right)$ \\
\end{tabular} & $\begin{array}{l}\text { Модельная } \\
\text { (расчётная) } \\
\text { Model } \\
\text { (calculated) } \\
\end{array}$ & $\begin{array}{c}\text { Разница расчётной } \\
\text { и измеренной } \\
\text { Difference between calcu- } \\
\text { lated and experimental } \\
\end{array}$ & \\
\hline $\mathrm{J}_{3} \mathrm{nn} / 2586$ & . & $\begin{array}{c}109 \\
(0,72) \\
\end{array}$ & 109 & ( & \multirow{6}{*}{$\begin{array}{c}\text { 54/квазистационарный, } \\
\text { начиная с юры до современного } \\
\text { 54/quasistationary, } \\
\text { from Jurassic to present }\end{array}$} \\
\hline $\mathrm{J}_{1-2} \mathrm{tm} / 2750$ & 100 & - & 101 & +1 & \\
\hline $\mathrm{J}_{1-2} \mathrm{tm} / 2797$ & - & $\begin{array}{c}117 \\
(0,78)\end{array}$ & 116 & -1 & \\
\hline $\mathrm{J}_{1-2} \mathrm{tm} / 2821$ & - & $\begin{array}{c}1117 \\
(0,78) \\
\end{array}$ & 117 & 0 & \\
\hline $\mathrm{J}_{1-2 \mathrm{tm}} / 2825$ & 103 & - & 103 & 0 & \\
\hline $\mathrm{J}_{1-2} \mathrm{tm} / 2838$ & - & $\begin{array}{c}116 \\
(0,77) \\
\end{array}$ & 117 & +1 & \\
\hline $\mathrm{C}_{1} \mathrm{kh} / 2908$ & - & $\begin{array}{c}170 \\
(1,17)\end{array}$ & 170 & 0 & $\begin{array}{c}\text { 224/квазистационарный, } \\
\text { начиная с силура } \\
\text { до резкого снижения в триасе } \\
\text { 224/quasistationary, } \\
\text { from Silurian to rapid decline in Triassic }\end{array}$ \\
\hline
\end{tabular}

*определения А.Н. Фомина (ИНГГ СО РАН, Новосибирск).

*Alexander N. Fomin determinations (Trofimuk Institute of Petroleum Geology and Geophysics of Siberian Branch of Russian Academy of Sciences, Novosibirsk).
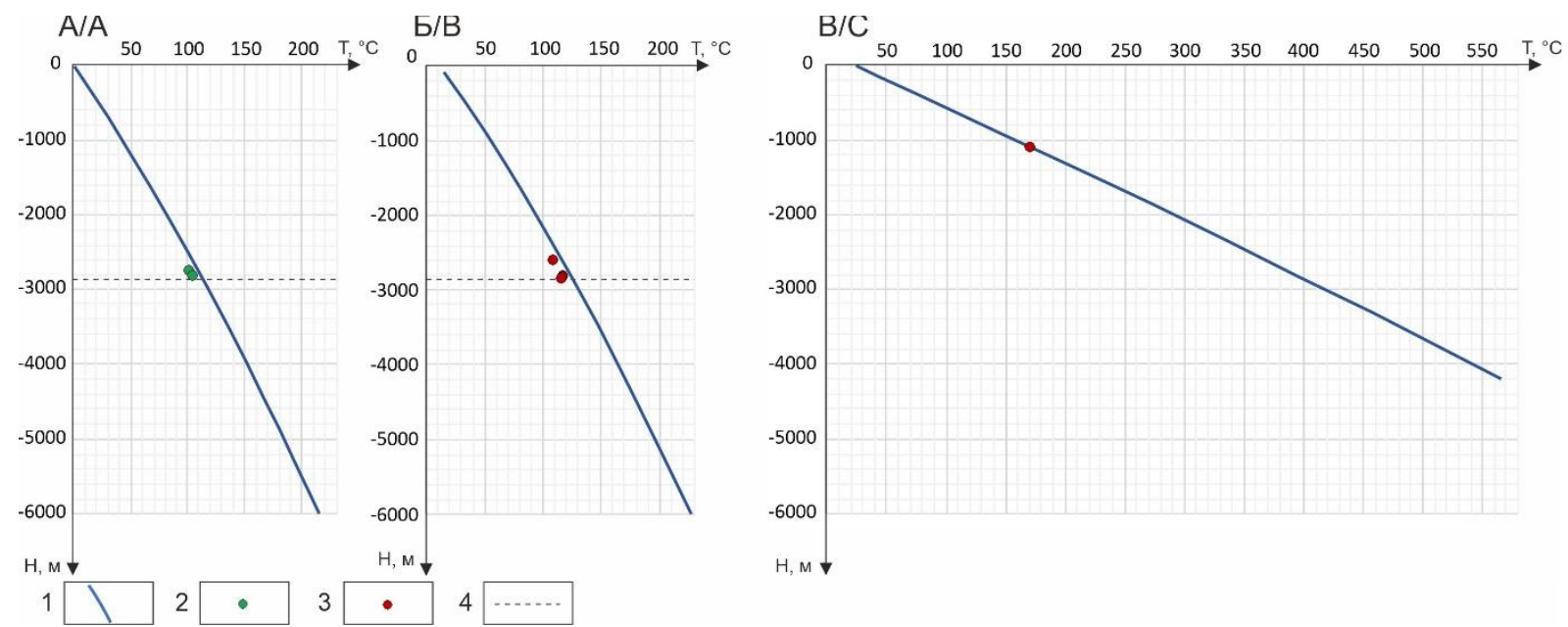

Рис. 3. Скважина Герасимовская 12. Расчетные и измеренные температуры для современного разреза (А), на время максимального прогрева осадочного чехла 24 млн лет назад - конеи палеогена (Б), на время 313 млн лет назад - максимальный прогрев палеозойского разреза (B): 1-3- температуры (1 - расчетные; 2 - измеренные пластовые; 3 - измеренные по ОСВ); 4 - положение подошвы осадочного чехла. 24 млн лет назад - время максимальной мочности юрско-палеогеновых отложений и начала резкого спада климатических температур в конце олигочена. 313 млн лет назад - время максимальной мощности палеозойского разреза, включая полную мощность еще не размытых каменноугольных отложений

Fig. 3. The well Gerasimov no. 12. Calculated and experimental temperatures in present geological section (A), at the time corresponding to maximum heating of sediment cover in the end of the Paleogene-24 Ma ago (B), at the time corresponding to maximum heating of the Paleozoic section - 313 Ma ago $(C)$ : 1-3 - temperatures (1 - calculated; 2 measured during well tests; 3 - measured by vitrinite reflectance (VR)); 4 - the bottom of sediment cover. 24 Ma ago - period of maximum burial depth of the Jurassic to Paleogene rocks and dramatically decline beginning of the climate temperatures in the Late Oligocene. 313 Ma ago - period of maximum burial depth of the Paleozoic rocks including the whole thickness of the Carboniferous rocks, which has not been eroded away yet 

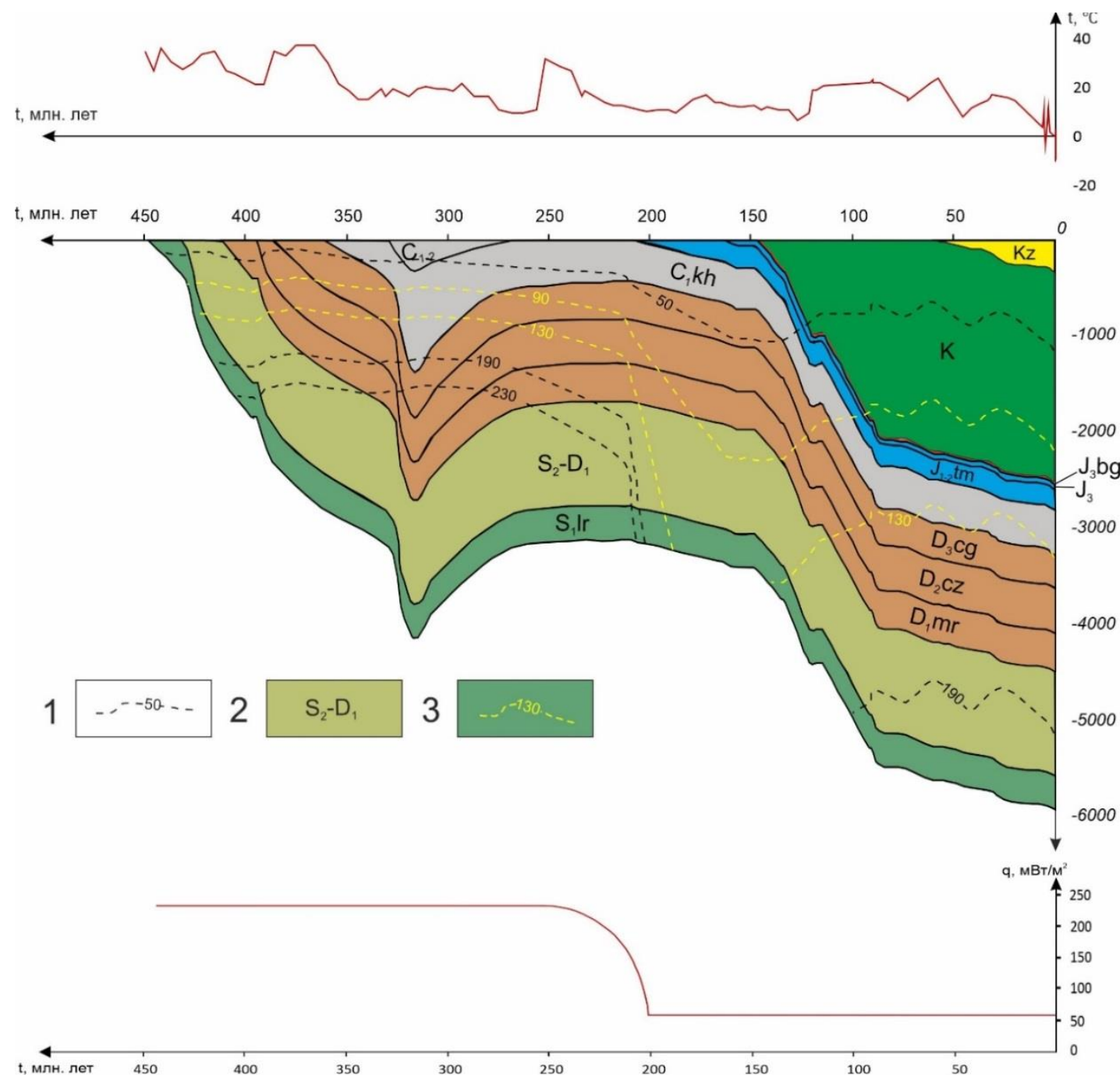

Рис. 4. Разрез скважины Герасимовская 12. Палеоструктурные и палеотемпературные реконструкиии: 1 - геоизотерма; 2 - стратиграфический индекс отложений; 3 - граничная изотерма ГФН. В нижней части рисунка демонстрируется изменение глубинного теплового потока, в верхней части - вековой ход климатических температур

Fig. 4. Geological section of the well Gerasimov no. 12. Paleotectonic and paleothermal reconstructions: 1 - isotherm; $2-$ stratigraphic index of rocks; 3 -isotherm of oil window border. At the bottom of the picture a curve of deep heat flow density is offered, at the top - a curve of secular changes of climate temperature

Катагенетическая история чузикской свиты $\left(D_{2} c z\right)$. Свита вошла в ГЗН 374 млн лет назад на значительный интервал геологического времени 23 млн лет, в ГЗГ - 351 млн лет назад на продолжительное время - 26 млн лет. Весьма вероятно, что нефтяной потенциал чузикского источника полностью реализован 351 млн лет назад, а газовый потенциал - 325 млн лет назад. С этого времени свита вошла в зону геотемператур, деструктивных для углеводородов. Свита находилась в этой зоне не менее 60 млн лет, т. е. до 324 млн лет назад. Вполне ясно, что углеводороды чузикского источника не могли питать залежи палеозойских горизонтов.

Катагенетическая история чагинской свиты $\left(D_{3} c g\right)$. Чагинская свита вошла в ГЗН 336 млн лет назад - на 12 млн лет, в ГЗГ - 325 млн лет назад на 5 млн лет. Вероятно, что нефтяной потенциал чагинского источника реализован 325 млн лет назад, а газовый потенциал - 320 млн лет назад. Начиная с
320 млн лет назад чагинская свита находится в зоне деструктивных геотемператур, т. е. порядка 7 млн лет до начала формирования коллекторов палеозойских горизонтов. Учитывая историю деструктивных геотемператур, маловероятно, что углеводороды чагинского источника могли питать залежи палеозойских горизонтов.

Катагенетическая история кехорегской свиты $\left(C_{l} k h\right)$. Кехорегская свита вошла в ГЗН 323 млн лет назад, но ненадолго - на 3 млн лет, в ГЗГ - первый раз 320 млн лет назад на весьма продолжительное время - 19 млн лет, и второй раз 24 млн лет назад еще на 20 млн лет. За свою историю палеозойская кехорегская свита не погружалась в зону деструктивных геотемператур. Если учесть последовательность фаз генерации и эмиграции жидких и газообразных углеводородов, а также временной период формирования палеозойских коллекторов, то можно с большой вероятностью ожидать аккумуляцию кехорегского газа в 
резервуарах палеозоя. Такой прогноз подтверждается результатами опробования скважин 7 и 12 (табл. 1): в интервалах палеозойских горизонтов, наряду с притоками нефти, получены притоки газа.

Катагенетическая история тюменской свиты $\left(J_{l-2} t m\right)$. Тюменская свита находится в ГЗН с 95 млн лет назад по настоящее время. Свита за свою историю не входила в зону деструктивных геотемператур. Следовательно, тюменская нефть может аккумулироваться в палеозойских резервуарах с 95 млн лет назад и по настоящее время, а геотемпературы резервуаров палеозоя вполне благоприятны для сохранности нефти тюменского источника. Такой предварительный прогноз подтверждается результатами опробования - в интервалах палеозойских горизонтов, как и в пластах тюменской свиты, получены притоки нефти (табл. 1, скважины 8 и 12).

Катагенетическая история баженовской свиты $\left(J_{3} b g\right)$. Баженовская свита находится в ГФН уже без малого 92 млн лет. Свита за свою историю не испытывала воздействия деструктивных температур. Баженовская нефть может аккумулироваться в палеозойских резервуapax с 92 млн лет назад и по настоящее время, а температурная история резервуаров палеозоя благоприятна для сохранности нефти баженовского источника. Такой предварительный прогноз подтверждается результатами опробования - в интервалах палеозойских горизонтов получены притоки жидких углеводородов (табл. 1).

\section{Заключение}

В результате выполненного для Герасимовского месторождения совместного палеотемпературного моделирования фанерозойских очагов генерации углеводородов мезозойских и палеозойских осадочных бассейнов выявлены и изучены вероятные сингенетичные источники залежей УВ в выветрелом и коренном палеозое, а именно: тюменский и баженовский источники нефти и кехорегский источник газа.

Основываясь на данных генетических анализов нефти из резервуаров палеозоя $[1,21,37]$, возможность аккумуляции тюменской нефти в палеозое исключается, поскольку палеозойские нефти генерированы сапропелевым ОВ. Поэтому нефти резервуаров палеозоя могут быть, скорее всего, именно баженовскими.

Вместе с тем источником газа резервуаров палеозоя скорее всего является «кехорегский» - породы доманикоидного типа кехорегской свиты. В отличие

\section{СПИСОК ЛИТЕРАТУРЫ}

1. Paleozoic-sourced petroleum systems of the Western Siberian Basin - What is the evidence? / E. Ablya, D. Nadezhkin, E. Bordyug, T. Korneva, E. Kodlaeva, R. Mukhutdinov, M.A. Sugden, Van Bergen P.F. // Organic Geochemistry. 2008. - V. 39. - № 8. - P. 1176-1184.

2. Генезис доюрских залежей нефти Рогожниковской группь месторождений (по результатам изучения вертикальной 30нальности алканов) / Ю.В. Коржов, В.И. Исаев, М.Я. Кузина Г.А. Лобова // Известия Томского политехнического университета. - 2013. - Т. 323. - № 1. - С. 51-56.

3. Галиева М.Ф., Алеева А.О., Исаев В.И. Очаги генерации углеводородов и их аккумуляция в доюрском разрезе Сельвейкинской площади глубокого бурения (Томская область) // Нефтега- от Останинского месторождения, где вклад доюрского источника газа (чагинский источник) в газонефтяные залежи составил всего 2 \% [6], доля кехорегского газа Герасимовского месторождения в газонефтяных залежах палеозоя может составлять порядка $20 \%$ (пример - скважина Герасимовская 7).

Подводя итог исследованиям в районе Герасимовского месторождения, на котором вскрытая кровля палеозоя представлена отложениями нижнего карбона, можно заключить, что основным («главным») источником УВ доюрских залежей является юрская «баженовская нефть». Наряду с этим и роль каменноугольного кехорегского источника газа для палеозойских горизонтов весьма значительна.

В заключение следует констатировать, что результаты палеотемпературных исследований разрезов Сельвейкинской площади [3], Останинского месторождения [6], а также настоящие исследования Герасимовского месторождения показывают, что альтернативные концепции «главного источника» палеозойских залежей УВ не являются взаимоисключающими. Представляется, что для палеозойских залежей источником жидких углеводородов (нефть), скорее всего, является верхнеюрская баженовская свита, а источником газообразных углеводородов (газа и газоконденсата) являются палеозойские породы доманикоидного типа.

Во введении были названы две основные концепции межпластовой вертикальной миграции углеводородов, формирующих залежи не только в палеозое, но и в юре. Первая концепция сводится к восходящей миграции УВ-флюидов, вторая декларирует нисходящую направленность вертикальной межпластовой миграции углеводородов из юрских свит в доюрский комплекс. В этом контексте результаты наших исследований на Останинской группе месторождений дают возможность отказаться от рассмотрения этих концепций как ортодоксально альтернативных.

Кроме того, мы надеемся, что, несмотря на дискуссионность авторских методологических и методических решений при моделировании и оценке роли очагов генерации УВ в формировании залежей «палеозойской» нефти, полученный результат и его анализ может быть интересен как в аспекте теоретических основ, так и практических следствий для прогнозирования продуктивности палеозойского комплекса Западной Сибири.

зовая геология. Теория и практика. - 2020. - T. 15. - № 3. URL: http://www.ngtp.ru/rub/2020/26_2020.html (дата обращения 10.02.2021)

4. Брехунцов А.М., Монастырев Б.В., Нестеров (мл.) И.И. Закономерности размещения залежей нефти и газа Западной Сибири // Геология и геофизика. - 2011. - № 8. - С. 1001-1012.

5. Конторович В.А. Тектоника и нефтегазоносность мезозойскокайнозойских отложений юго-восточных районов Западной Сибири. - Новосибирск: Изд-во СО РАН, 2002. - 253 с.

6. Палеотемпературное моделирование очагов генерации углеводородов и их роль в формировании залежей «палеозойской» нефти (Останинское месторождение, Томская область) / В.И. Исаев, М.Ф. Галиева, А.О. Алеева, Г.А. Лобова, В.И. Старостенко, А.Н. Фомин // Георесурсы. - 2021. - № 1. - С. 2-15. 
7. Мезозойско-кайнозойский климат и неотектонические события как факторы реконструкции термической истории нефте материнской баженовской свиты арктического региона Западной Сибири (на примере п-ва Ямал) / В.И. Исаев, А.А. Искоркина, Г.А. Лобова, В.И. Старостенко, С.А. Тихоцкий, А.Н. Фомин // Физика Земли. - 2018. - № 2. - С. 124-144.

8. Handhal A.M., Al-Shahwan M.F., Chafeet H.A. Interpretation of hydrocarbon generation, migration and thermal history of Mesopotamian basin Southern Iraq based 1D Petromod software // Iraqi Geological Journal. - 2020. - V. 53. - № 1B. - P. 29-56.

9. Объёмная геолого-геотермическая модель осадочного чехла северо-восточной части Баренцевоморского шельфа в связи с освоением ресурсов углеводородов / Д.С. Никитин, Д.А. Иванов, В.А. Журавлев, М.Д. Хуторской // Георесурсы. - 2015. № 1. - С. 13-19.

10. Филиппов Ю.Ф., Бурштейн Л.М. История генерации нафтидов в Предъенисейском осадочном бассейне // Недропользование Горное дело. Направления и технологии поиска, разведки и разработки месторождений полезных ископаемых. Экономика. Геоэкология: Сборник материалов. В 4 т. Т. 1. - Новосибирск: ИНГГ СО РАН, 2017. - С. 166-170.

11. Thermal history of Canadian Williston basin from apatite fissiontrack thermochronology - implications for petroleum systems and geodynamic history / K.G. Osadetz, B.P. Kohn, S. Feinstein, P.B. O'Sullivan // Tectonophysics. - 2002. - V. 349. - № 1-4. P. 221-249. URL: https://doi.org/10.1016/ S0040-1951(02)00055-0 (дата обращения 10.02.2021).

12. Heat flow evolution, subsidence and erosion in the RhenoHercynian orogenic wedge of central Europe / R. Littke, C. Büker, M. Hertle, H. Karg, V. Stroetmann-Heinen, O. Oncken // Geological Society Special Publication. - 2000. - V. 179. P. 231-255. DOI: 10.1144/GSL.SP.2000.179.01.15

13. Reflectance of dispersed vitrinite in Palaeozoic rocks with and without cleavage: Implications for burial and thermal history modeling in the Devonian of Rursee area, northern Rhenish Massif, Germany / R. Littke, J.L. Urai, A.K. Uffmann, F. Risvanis // International Journal of Coal Geology. - 2012. - V. 89. - P. 41-50. URL: https://doi.org/10.1016/j.coal. 2011.07.006 (дата обращения 10.02.2021).

14. Paleo-heat flow evolution of the Tabei Uplift in Tarim Basin, northwest China / M. Li, T. Wang, J. Chen, F. He, L. Yun S. Akbar, W. Zhang // Journal of Asian Earth Sciences. - 2010. V. 37. - № 1. - P. 52-66. URL: https://doi.org/10.1016/j.jseaes. 2009.07.007 (дата обращения 10.02.2021)

15. Terrestrial heat flow and crustal thermal structure in the northern slope of Tazhong uplift in Tarim Basin / Y. Liu, N. Qiu, H. Li, A. Ma, J. Chang, J. Jia // Geothermics. - 2020. - V. 83. - P. 1-14. URL: https://doi.org/10.1016/j.geothermics. 2019.101709 (дата обращения 10.02.2021).

16. Палеобассейны - новая концепция моделирования истории геологического развития и нефтегазоносности регионов А.В. Ступакова, А.А. Пашали, В.В. Волянская, А.А. Суслова, А.П. Завьялова // Георесурсы. - 2019. - Т. 21. - № 2. - С. 4-12.

17. Сурков В.С., Жеро О.Г. Фундамент и развитие платформенного чехла Западно-Сибирской плиты. - М.: Недра, 1981. - 143 с

18. Стратиграфия нефтегазоносных бассейнов Сибири в 9 кн. Кн. 5: Палеозой Западной Сибири / под ред. А.Э. Конторовича - Новосибирск: Изд-во СО РАН, 2001. - 163 с.

19. Исаев Г.Д. Региональные стратиграфические подразделения палеозоя Западно-Сибирской плиты (по данным исследования табулятоморфных кораллов) // Вестник Томского государственного университета. - 2012. - № 355. - С. 161-168.

20. Запивалов Н.П., Исаев Г.Д. Критерии оценки нефтегазоносности палеозойских отложений Западной Сибири // Вестник Томского государственного университета. - 2010. - № 341. C. 226-232.

21. Фомин А.Н. Катагенез органического вещества и нефтегазоносность мезозойских и палеозойских отложений ЗападноСибирского мегабассейна. - Новосибирск: ИНГГ СО РАН, 2011. $-331 \mathrm{c}$.
22. Theissen S., Rüpke L.H. Feedbacks of sedimentation on crustal heat flow: New insights from the Voring Basin, Norwegian Sea // Basin Research - 2010. - V. 22. - P. 976-990. URL: https://doi.org/10.1111/j.1365-2117.2009.00437.x (дата обращения 10.02.2021)

23. Fuchs S., Balling N., Mathiesen A. Deep basin temperature and heat-flow field in Denmark - New insights from borehole analysis and 3D geothermal modelling // Geothermics. -2020 . - V. 83. P. 1-18. URL: https://doi.org/10.1016/ j.geothermics.2019.101722 (дата обращения 10.02.2021).

24. Towards stratigraphic-thermo-mechanical numerical modelling: Integrated analysis of asymmetric extensional basins / A. Balázs, L. Matenco, D. Granjeon, K. Alms, T. François, O. Sztanó // Global and Planetary Change. - 2021. - V. 196. - P. 1-21. URL: https://doi.org/10.1016/j.gloplacha.2020.103386 (дата обращения 10.02.2021)

25. Hantschel T., Kauerauf A.I. Fundamentals of basin and petroleum systems modeling. - Heidelberg: Springer, 2009. - $476 \mathrm{p}$.

26. Heat flow evolution, subsidence and erosion in Upper Silesian Coal Basin, Czech Republic / E. Geršlová, M. Goldbach, M. Geršl, P. Skupien // International Journal of Coal Geology. - 2016. V. 154-155. - P. 30-42. URL: https://doi.org/10.1016/j.coal.2015. 12.007 (дата обращения 10.02.2021)

27. Iskorkina A.A., Isaev V.I., Terre D.A. Assessment of MesozoicKainozoic climate impact on oil-source rock potential (West Siberia) // IOP Conf. Series: Earth and Environmental Science 27 (2015) 012023. URL: http://iopscience.iop.org/article/10.1088/ 1755-1315/27/1/012023/pdf (дата обращения 10.02.2021).

28. Scotese C. A new global temperature curve for the Phanerozoic // GSA Annual Meeting. Abstracts with Programs. - Denver, Colorado, 2016. - V. 48. - № 7. - P. 24-31.

29. Исаев В.И., Волкова Н.А., Ним Т.Г. Решение прямой и обратной задачи геотермии в условиях седиментации // Тихоокеанская геология. - 1995. - № 3. - С. 73-80.

30. Старостенко В.И. Устойчивые численные методы в задачах гравиметрии. - Киев: Наук. Думка, 1978. - 228 с.

31. Исаев В.И. Интерпретация данных высокоточной гравиразведки методами математического программирования // Тихоокеанская геология. - 2013. - Т. 32. - № 2. - С. 29-43.

32. Модель катагенеза органического вещества (на примере баженовской свиты) / Л.М. Бурштейн, Л.В. Жидкова, А.Э. Конторович, В.Н. Меленевский // Геология и геофизика. - 1997. - № 6. - С. 1070-1078.

33. Optical thermal maturity parameters and organic geochemical alteration at low grade diagenesis to anchimetamorphism: a review / C. Hartkopf-Fröder, P. Königshof, R. Littke, J. Schwarzbauer // International Journal of Coal Geology. 2015. - V. 150. - P. 74-119. URL: http://dx.doi.org/10.1016/ j.coal.2015.06.005 (дата обращения 10.02.2021).

34. Неручев С.Г., Рогозина Е.А., Капченко Л.Н. Главная фаза газообразования - один из этапов катагенетической эволюции сапропелевого рассеянного органического вещества // Геология и геофизика. - 1973. - № 10. - С. 14-16.

35. Gas formation. Formation temperatures of thermogenic and biogenic methane / D.A. Stolper, M. Lawson, C.L. Davis, A.A. Ferreira, E.V. Santos Neto, G.S. Ellis, M.D. Lewan, A.M. Martini, Y. Tang, M. Schoell, A.L. Sessions, J.M. Eiler // Science (New York, N.Y.). - 2014. - V. 344 (6191). - P. 1500-1503. DOI: $10.1126 /$ science. 1254509

36. Белозеров В.Б., Гарсия Бальса А.С. Перспективы поиска залежей нефти в отложениях девона юго-восточной части Западно-Сибирской плиты // Известия Томского политехнического университета. Инжиниринг георесурсов. - 2018. - Т. 329. № 6. - C. 128-139.

37. Костырева Е.А. Геохимия и генезис палеозойских нефтей юго-востока Западной Сибири // Геология и геофизика. 2004. - T. 45. - № 7. - C. 843-853.

Поступила 24.02.2021 2. 


\section{Информация об авторах}

Исаев В.И., доктор геолого-минералогических наук, профессор отделения геологии Инженерной школы природных ресурсов Национального исследовательского Томского политехнического университета.

Галиева М.Ф., студент отделения геологии Инженерной школы природных ресурсов Национального исследовательского Томского политехнического университета.

Лобова Г.А., доктор геолого-минералогических наук, профессор отделения геологии Инженерной школы природных ресурсов Национального исследовательского Томского политехнического университета.

Крутенко Д.С., студент отделения геологии Инженерной школы природных ресурсов Национального исследовательского Томского политехнического университета.

Ocunoва $\boldsymbol{E} . \boldsymbol{H}$., кандидат геолого-минералогических наук, старший преподаватель отделения геологии Инженерной школы природных ресурсов Национального исследовательского Томского политехнического университета. 
UDC 553.98

\title{
MODELLING OF PHANEROZOIC FOCI OF HYDROCARBON GENERATION TO ASSESS THEIR ROLE IN FORMATION OF THE PALEOZOIC OIL DEPOSITS (SOUTHEASTERN OF WESTERN SIBERIA)
}

\author{
Valery I. Isaev ${ }^{1}$, \\ isaevvi@tpu.ru
}

Margarita F. Galieva ${ }^{1}$,

Galina A. Lobova1, lobovaga@tpu.ru

Daniil S. Krutenko1, dskrutenko@gmail.com

Elizaveta N. Osipova ${ }^{1}$ osipovaen@tpu.ru

1 National Research Tomsk Polytechnic University, 30, Lenin avenue, Tomsk, 634050, Russia.

The relevance. Commercially producible volumes of oil and gas from the Paleozoic play are defined within all territory of Western Siberia. Extensive work to assess the amount of the pre-Jurassic hydrocarbon resources was performed in southeastern. There 13 hydrocarbon deposits were discovered in calcareous, siliceous and clayey, sandy and gravelite rocks. These objects are relegated to hard-to-recover resources, but at the same time are regarded as investment attractive in the reason of location in territories of oil fields with well-developed infrastructure. This study states and solves the issue concerning modelling of the Mesozoic and the Paleozoic catagenic foci of hydrocarbon generation and performs the assessment of their role in formation of the Paleozoic oil deposits.

The main aim of the research is to assess the role of the Phanerozoic foci of hydrocarbon generation in formation of the Paleozoic oil deposits.

Objects. This paper involves setting and solving the issue regarding to paleotectonic and paleotemperature reconstructions of the Paleozoic and the Mesozoic foci of hydrocarbon generation in the section of the Gerasimov oil-gas condensate field, which is located within the Ostanino group of fields in Tomsk region. Reservoirs of the weathered and the inner Paleozoic - Lower Carboniferous Kehoreg suite are occasioned with epigenetic processes in old weathering crust in period of 213-208 Ma ago. Database on the field includes well test temperatures and vitrinite reflectance data both as from the Jurassic, so from the pre-Jurassic sections and also documented information about fluid inflows from the pre-Jurassic play.

Methods. Paleoreconstruction is carried out by paleotemperature modelling method. The applied model does not require making final calibrations with vitrinite reflectance data. Deep heat flow is determined by solving inverse problem of Geothermy using proprietary approach including two steps. The first step involves density estimation of the quasistationary heat flow associated with the beginning of the Jurassic period. The second step intends to determine heat flow value in the Silurian and its dynamics until the Early Jurassic. Depositional and thermal history of the Phanerozoic source rocks (the Paleozoic formations: Larin, Mir, Chuzik, Chagin, Kehoreg; and the Jurassic formations: Tyumen, Bazhenov) is restored by solving direct problems of Geothermy.

Results. Co-generating sources of hydrocarbon deposits in the weathered and the inner Paleozoic were defined and studied as a result of performing coupled paleotemperature modelling of the Phanerozoic foci of hydrocarbon generation in the Mesozoic and the Paleozoic sedimentary basins. Accountancy of succession of generation and oil and gas migration, timeframe of reservoirs formation, oil origin analysis data allows identifying oil from the Paleozoic reservoirs as Bazhenov oil. Domanic rocks of Kehoreg suite are accepted as a gas source for Paleozoic reservoirs.

The conclusion. Paleotemperature study of the Gerasimov field section and modelling within the Selveikin area of deep drilling and the Ostanino field performed earlier show that two alternative concepts of the main source for the Paleozoic hydrocarbon deposits are not mutually exclusive. It seems that for the Paleozoic deposits an oil source rock, more likely, is the Upper Jurassic Bazhenov formation and a gas source rock (for generating gas and condensate) is the Paleozoic domanic rocks.

\section{Key words:}

Paleozoic oil and gas play, Phanerozoic hydrocarbon sources, paleotemperature modelling of foci of hydrocarbon generation, co-generating sources of the Paleozoic oil, the Ostanino field group in Tomsk region.

\section{REFERENCES}

1. Ablya E., Nadezhkin D., Bordyug E., Korneva T., Kodlaeva E., Mukhutdinov R., Sugden M.A., P.F. van Bergen. Paleozoicsourced petroleum systems of the Western Siberian Basin - What is the evidence? Organic Geochemistry, 2008, vol. 39, no. 8, pp. 1176-1184.

2. Korzhov Yu.V., Isaev V.I., Kuzina M.Ya., Lobova G.A. Genesis of the pre-Jurassic oil deposits of the Rogozhnikovo group of fields (based on results of vertical alkanes zoning studying). Bulletin of the Tomsk Polytechnic University, 2013, vol. 323, no. 1, pp. 51-56. In Rus.

3. Galieva M.F., Aleeva A.O., Isaev V.I. Hydrocarbons in preJurassic section within Selveikinskaya area of deep drilling: foci of generation and accumulation (Tomsk Region). Neftegazovaya Geologiya. Teoriya i Praktika, 2020, vol. 15, no. 3. In Rus. Available at: http://www.ngtp.ru/rub/2020/26_2020.html (accessed 10 February 2021). 
4. Brekhuntsov A.M., Monastyrev B.V., Nesterov I.I. Distribution patterns of oil and gas accumulations in West Siberia. Russian Geology and Geophysics, 2011, vol. 52, no. 8, pp. 781-791. In Rus.

5. Kontorovich V.A. Tektonika $i$ neftegazonosnost mezozoyskokaynozoyskikh otlozheniy yugo-vostochnykh rayonov Zapadnoy Sibiri [Tectonics and oil and gas potential of the Mesozoic and Cenozoic rocks in the south-eastern part of Western Siberia]. Novosibirsk, SO RAN Publ., 2002. 253 p.

6. Isaev V.I., Galieva M.F., Aleeva A.O., Lobova G.A., Starostenko V.I., Fomin A.N. Paleotemperature modelling: hydrocarbon foci of generation and their role in formation of the Paleozoic oil deposits (a study of the Ostanino field, Tomsk Region) Georesources, 2021, no. 1, pp. 2-15. In Rus.

7. Isaev V.I., Iskorkina A.A, Lobova G.A., Starostenko V.I., Tikhotskii S.A., Fomin A.N. Mesozoic-Cenozoic Climate and Neotectonic Events as Factors in Reconstructing the Thermal History of the Source-Rock Bazhenov Formation, Arctic Region, West Siberia, by the Example of the Yamal Peninsula. Izvestiya. Physics of the Solid Earth, 2018, vol. 54, no. 2, pp. 310-329. In Rus.

8. Handhal A.M., Al-Shahwan M.F., Chafeet H.A. Interpretation of hydrocarbon generation, migration and thermal history of Mesopotamian basin Southern Iraq based 1D Petromod software. Iraqi Geological Journal, 2020, vol. 53, no. 1B, pp. 29-56.

9. Nikitin D.S., Ivanov D.A., Zhuravlev V.A., Khutorskoy M.D. Three-dimensional geological and geothermal model of sedimentary cover in the north-eastern part of the Barents sea shelf in connection with the development of hydrocarbon resources. Georesources, 2015, no. 1, pp. 13-19. In Rus.

10. Filippov Yu.F., Burshteyn L.M. History of oil and gas generation of the Pre-Yenisey sedimentary basin. Nedropolzovanie. Gornoe delo. Napravleniya i tekhnologii poiska, razvedki i razrabotki mes torozhdeniy poleznykh iskopaemykh. Ekonomika. Geoekologiya [Subsurface resources management. Mining engineering. Directions and technologies of prospection, exploration and development of mineral deposits. Economics. Geoecology]. Novosibirsk, SO RAN Publ., 2017. Vol. 1, pp. 166-170. In Rus.

11. Osadetz K.G., Kohn B.P., Feinstein S., O'Sullivan P.B. Thermal history of Canadian Williston basin from apatite fission-track thermochronology - implications for petroleum systems and geodynamic history. Tectonophysics, 2002, vol. 349, no. 1-4, pp. 221-249. Available at: https://doi.org/10.1016/S0040-1951(02 00055-0 (accessed 10 February 2021).

12. Littke R., Büker C., Hertle M., Karg H., Stroetmann-Heinen V., Oncken O. Heat flow evolution, subsidence and erosion in the Rheno-Hercynian orogenic wedge of central Europe. Geological Society Special Publication, 2000, vol. 179, pp. 231-255. DOI: 10.1144/GSL.SP.2000.179.01.15

13. Littke R., Urai J.L., Uffmann A.K., Risvanis F. Reflectance of dispersed vitrinite in Palaeozoic rocks with and without cleavage: Implications for burial and thermal history modeling in the Devonian of Rursee area, northern Rhenish Massif, Germany. International Journal of Coal Geology, 2012, vol. 89, pp. 41-50. Available at: https://doi.org/10.1016/j.coal.2011.07.006 (accessed 10 February 2021).

14. Li M., Wang T., Chen J., He F., Yun L., Akbar S., Zhang W. Paleo-heat flow evolution of the Tabei Uplift in Tarim Basin northwest China. Journal of Asian Earth Sciences, 2010, vol. 37 , no. 1, pp. 52-66. Available at: https://doi.org/10.1016/j.jseaes. 2009.07.007 (accessed 10 February 2021).

15. Liu Y., Qiu N., Li H., Ma A., Chang J., Jia J. Terrestrial heat flow and crustal thermal structure in the northern slope of Tazhong uplift in Tarim Basin. Geothermics, 2020, vol. 83, pp. 1-14. Available at: https://doi.org/10.1016/j.geothermics.2019.101709 (accessed 10 February 2021)

16. Stoupakova A.V., Pashali A.A., Volyanskaya V.V., Suslova A.A., Zavyalova A.P. Paleobasins - a new concept of modeling the history of geological development and oil and gas bearing of regions. Georesources, 2019, vol. 21, no. 2, pp. 4-12. In Rus.

17. Surkov V.S., Zhero O.G. Fundament $i$ razvitie platformennogo chekhla Zapadno-Sibirskoy plity [The basement and platform development of Western Siberian Plate]. Moscow, Nedra Publ., 1981 $143 \mathrm{p}$.

18. Stratigrafiya neftegazonosnykh basseynov Sibiri [Stratigraphy of oil and gas basins of Siberia]. Vol. 5. Paleozoy Zapadnoy Sibiri
[The Paleozoic of Western Siberia]. Ed. by A.E. Kontorovich. Novosibirsk, SB RAS Publ. house, 2001. 163 p.

19. Isaev G.D. Regional stratigraphic subdivisions of the Paleozoic of the West-Siberian plate. Tomsk State University Journal, 2012, no. 355, pp.161-168. In Rus.

20. Zapivalov N.P., Isaev G.D. Criteria of estimation of oil-and-gasbearing Palaeozoic deposits of Western Siberia. Tomsk State University Journal, 2010, no. 341, pp. 226-232. In Rus.

21. Fomin A.N. Katagenez organicheskogo veshchestva i neftegazonosnost mezozoyskikh $i$ paleozoyskikh otlozheniy ZapadnoSibirskogo megabasseyna [Catagenesis of organic matter and oiland-gas of the Mesozoic and Paleozoic deposits of the Western Siberian megabasin]. Novosibirsk, Institute of Petroleum Geology and Geophysics of the SB RAS Publ. house, 2011.331 p.

22. Theissen S., Rüpke L.H. Feedbacks of sedimentation on crustal heat flow: new insights from the Voring Basin, Norwegian Sea. Basin Research, 2010, vol. 22, pp. 976-990. Available at: https:// doi.org/10.1111/j.1365-2117.2009.00437.x (accessed 10 February 2021).

23. Fuchs S., Balling N., Mathiesen A. Deep basin temperature and heat-flow field in Denmark - New insights from borehole analysis and 3D geothermal modelling. Geothermics, 2020, vol. 83, pp. 1-18. Available at: https://doi.org/10.1016/j.geothermics. 2019.101722 (accessed 10 February 2021).

24. Balázs A., Matênco L., Granjeon D., Alms K., François T., Sztanó O. Towards stratigraphic-thermo-mechanical numerical modelling: integrated analysis of asymmetric extensional basins. Global and Planetary Change, 2021, vol. 196, pp. 1-21. Available at: https://doi.org/10.1016/j.gloplacha.2020.103386 (accessed 10 February 2021).

25. Hantschel T., Kauerauf A.I. Fundamentals of basin and petroleum systems modeling. Heidelberg, Springer, 2009. $476 \mathrm{p}$.

26. Geršlová E., Goldbach M., Geršl M., Skupien P. Heat flow evolution, subsidence and erosion in Upper Silesian Coal Basin, Czech Republic. International Journal of Coal Geology, 2016, vol. 154-155, pp. 30-42. Available at: https://doi.org/10.1016/ j.coal.2015.12.007

27. Iskorkina A.A., Isaev V.I., Terre D.A. Assessment of MesozoicKainozoic climate impact on oil-source rock potential (West Siberia). IOP Conf. Series: Earth and Environmental Science, 27, 2015, 012023. Available at: http://iopscience.iop.org/article/10.1088/ 1755-1315/27/1/012023/pdf (accessed 10 February 2021).

28. Scotese C. A new global temperature curve for the Phanerozoic. GSA Annual Meeting. Abstracts with Programs. Denver, Colorado, 2016. Vol. 48, no. 7, pp. 24-31.

29. Isaev V.I., Volkova N.A., Nim T.V. Solution of direct and inverse sedimentation heat-flow problems. Geology of the Pacific Ocean, 1996, vol. 12, no. 3, pp. 523-536. In Rus.

30. Starostenko V.I. Ustoychivye chislennye metody $v$ zadachakh gravimetrii [Sustainable numerical methods in Gravimetry issues]. Kiev, Nauk. Dumka Publ., 1978. 228 p.

31. Isaev V.I. Interpretation of high-accuracy gravity exploration data by mathematic programming. Russian Journal of Pacific Geology, 2013, vol. 7, no. 2, pp. 92-106. In Rus.

32. Burshtein L.M., Zhidkova L.V., Kontorovich A.E., Melenevskii V.N. Model of catagenesis of organic matter (by using the example of the Bazhenovka Formation). Russian Geology and Geophysics, 1997, vol. 38, no. 6, pp. 1107-1115.

33. Hartkopf-Fröder C., Königshof P., Littke R., Schwarzbauer J. Optical thermal maturity parameters and organic geochemical alteration at low grade diagenesis to anchimetamorphism: a review. $I n$ ternational Journal of Coal Geology, 2015, vol. 150, pp. 74-119. Available at: http://dx.doi.org/10.1016/j.coal. 2015.06.005 (accessed 10 February 2021).

34. Neruchev S.G., Rogozina E.A., Kapchenko L.N. Glavnaya faza gazoobrazovaniya - odin iz etapov katageneticheskoy evolyutsii sapropelevogo rasseyannogo organicheskogo veshchestva [Main phase of petroleum generation as a stage of catagenetic evolution of dispersed sapropelic vegetable organic matter]. Geologiya $i$ Geofizika, 1973, no. 10, pp. 14-17.

35. Stolper D.A., Lawson M., Davis C.L., Ferreira A.A., Santos Neto E.V., Ellis G.S., Lewan M.D., Martini A.M., Tang Y., Schoell M., Sessions A.L., Eiler J.M.. Gas formation. Formation temperatures of thermogenic and biogenic methane. Science (New York, N.Y.), 
2014, vol. 344 (6191), pp. 1500-1503. DOI: 10.1126/science. 1254509

36. Belozerov V.B., Garcia A.S. Prospects of searching for oil reservoirs in the Devonian deposits of the south-eastern part of the Western-Siberian plate. Bulletin of the Tomsk Polytechnic University. Geo Assets Engineering, 2018, vol. 329, no. 6, pp. 128-139. In Rus.

\section{Information about the authors}

Valery I. Isaev, Dr. Sc., professor, National Research Tomsk Polytechnic University.

Margarita F. Galieva, student, National Research Tomsk Polytechnic University.

Galina A. Lobova, Dr. Sc., professor, National Research Tomsk Polytechnic University.

Daniil S. Krutenko, student, National Research Tomsk Polytechnic University.

Elizaveta N. Osipova, Cand. Sc., senior lecturer, National Research Tomsk Polytechnic University. 